\begin{tabular}{c} 
Volume and Issues Obtainable at Center for Sustainability Research and Consultancy \\
Journal of Business and Social Review in Emerging Economies \\
ISSN: 2519-089X (E): 2519-0326 \\
Volume 5: No. 2, December 2019 \\
ᄃSRᄃ \\
Journal homepage: www.publishing.globalcsrc.org/jbsee \\
\hline
\end{tabular}

\title{
An International Investigation of the Institutional Factors Driving Sustainability Assurance
}

\author{
${ }^{1}$ Allah Bakhsh, ${ }^{2}$ Zeeshan Mahmood, ${ }^{3}$ Abu Bakar Mahmood \\ ${ }^{1}$ Assistant Professor, Department of Commerce, Bahauddin Zakariya University, Multan, Pakistan: \\ abkhan@bzu.edu.pk \\ ${ }^{2}$ Assistant Professor, Department of Commerce, Bahauddin Zakariya University, Multan, Pakistan: \\ zeeshanmahmood@bzu.edu.pk \\ ${ }^{3}$ Research Scholar, Department of Commerce, Bahauddin Zakariya University, Multan, Pakistan
}

\begin{tabular}{l} 
ARTICLE DETAILS \\
\hline History \\
Revised format: November 2019 \\
Available Online:December 2019
\end{tabular}

ABSTRACT

\section{Keywords}

Sustainability Assurance, stakeholder Orientation, Voice, Accountability, rule of Law, cultural Orientation. Global Reporting Index (GRI)

JEL Classification:

Q56, C43, C49

This paper investigates the impact of various factors associated with the adoption of sustainability assurance. Our objective is to find out the impact of country-level institutional factors (stakeholder orientation, voice and accountability, rule of law, investors'protection and long-term orientation) on sustainability assurance. Extant literature is scarce at country-level and specifically does not address the impact of culturalorientation on sustainability assurance. This paper fills the gap and focuses on the cultural dimension (long-term orientation) in addition to other country-level institutional factors. Companies listed on the Sustainability Disclosure Database (http://database.globalreporting.org) constitute the population for this study. We filtered companies of large size from sustainability-sensitive industries which produced GRI-based reports in the year 2017. Our final sample comprised 196 companies from 41 countries. Using linear regression model, our results suggest that companies that are located in countries with weaker investor protections, greater rule of law, greater voice and accountability, and long-term orientation are more likely to adopt sustainability assurance whereas companies that are located in stakeholder-oriented countries are less likely to adopt sustainability assurance. This paper contributes to the existing literature by providing empirical evidence of the impact of cultural dimensions on sustainability assurance. Future research can explore other dimensions of culture and their impact on sustainability assurance.

(C) 2019 The authors, under a Creative Commons Attribution-

NonCommercial 4.0

Corresponding author's email address: abkhan@bzu.edu.pk

Recommended citation: Bakhsh, A., Mahmood, Z. and Mahmood, A. B., (2019). An International Investigation of the Institutional Factors Driving Sustainability Assurance. Journal of Business and Social Review in Emerging Economies, 5 (2), 367-378

DOI: $10.26710 /$ jbsee.v5i2.925

\section{Introduction}

At present, the World is facing a variety of sustainability issues including climate change, labour rights and shortage of water, global warming and destruction of forests. The world at present is estimated to abodes about 9 billion population but the resources on the earth are not sustained. Consequently, most of the peoples would not be able to fulfil their basic needs (food, cloth and shelter) of life. In such 
circumstances, we need to manage and utilise our resources and activities optimally. To monitor the organizational activities and address the organizational performance foe better serving stakeholders, accounting techniques may play an important role.

Traditional accounting methods are not adequate to achieve the desired result for the organizational operations and some alternative approaches ought to be employed to analysing and recoding the companies' economic, social and environmental performances. Consequently, a set of substitute accounting policies such as sustainability reporting and their assurance to stakeholders may overcome these challenges and expand their operations on a more developed sustainable pattern.

Corporate sustainability reporting and assurance are modern terms introduced to support corporate to achieving a sustainable growth. Sustainability assurance is taken as dependent variable whereas variables like Stakeholders-orientation, Investors' protection, Rule of Law, Voice and Accountability and Hofstede's Dimensions (Long term orientation) as the likely factors affecting it. Some studies show negative results with sustainability assurance, others depict a positive relationship with them and some of them are even not sure about any relationship between them. Some countries more favourably adopt the independent third-party assurance over their sustainability reports to enhance the credibility of their firms by bearing an extra cost.

Most of the existing studies determine the relationship individually or take 2 independent variables with sustainability assurance. This study takes five country-level determinants to check the relationship with sustainability assurance. There is not any past study related to the Hofstede's dimension relationship with the sustainability assurance.

The research questions of this study are:

- Do stakeholders-oriented countries adopt sustainability assurance or not. ?

- What is impact on sustainability assurance adoption in the countries where Investors' protection deviates?

- Do Voice and Accountability affect adoption of sustainability assurance?

- What is impact on sustainability assurance in those countries where Rule of Law is stronger or weaker?

- Does Sustainability assurance, more or less is adopted in those countries which are Long-oriented (Hofstede's Dimension)?

\section{Literature Review \& Hypotheses Development}

The term "sustainability accounting" describes the usage of accounting and non-accounting policies to strengthen the sustainable development (Lamberton, 2005). The main focus of this study is to describe the phenomena of sustainability reporting and their assurance over independent third party. Fama and Jensen (1983) describe that mostly agency cost conflict arises due to information disclosure between different stakeholders. With adopting the practices of sustainability reporting, this barrier may be eliminated.

Sustainability reporting has gained considerable attention amongst multinational corporations around the world in last 20 years. Voluntary disclosures of information regarding economic, social and environmental effects of their implementations are main cause to initiate the sustainability accounting. Several studies recognize that there is rising awareness to implement the sustainability reporting practices in the organization. Around $85 \%$ results show from sample of 500 companies that companies were issued a sustainability reporting in 2010 (Junior et al. 2014)

These studies help to deliver the appreciated results because while testing the balance of sustainability reporting, there is reason to check other materiality issues. If issue is related to organization and 
stakeholder values, then it must be considered as material. Only if companies fail to address material issues properly, then sustainability reporting can be described as a validity tool.

As non-accounting policies have surfaced, different problems are also initiated in the meanwhile, like reliability of reports. The reliability issues refer to another new market called third-party assurance of sustainability reports. The primary agenda of sustainability assurance is to create trust of stakeholders over reliability of reports. Sustainability assurances is relatively a new terminology as compared to sustainability reporting and have a broader domain with emerging practices which is growing along its several dimensions.

Numerous studies state that assurance positively impacts stakeholder's perceived reliability regarding reports. Assurance provides additional benefits like improvements to system and processes which are grounds of sustainability reporting and continuously improvement in their quality. Different scholars claim that assurance does not only provide the credibility of sustainability reports but also depicts value added information to internal management.

On supply side, sustainability assurance market is designed with several various sustainability assurance providers (called SAPs) which are competing for a share of the market. SAPs providers are divided into two basic categories of accounting SAPs (ASAPs) and non-accounting SAPs (NASPs). ASAPs consist of "the Big Four accounting firms" which entered in the market for looking the additional income source. Over the time, the market share of ASAPs has continuously growing and placing them in a clear position in most countries.

ASAPs lemmatised the occurrence of sustainability assurance engagement to confirm the reliability and validity of information and data found in the sustainability reports. These engagement not involved the SAP assurance over the level of balance (i.e. disclosure over the material good news versus bad news) contained in the sustainability reports. NASAP are persuade to commence better scope engagements involved assurance over reliability of information also an evaluation of balanced sustainability reports. Many are doubtful of the ability of sustainability assurance to increase credibility of sustainability reports.As non-accounting reporting is emerged, new problems have risen in current time such as credibility and quality of reports (Guidry and Patten, 2010). Past studies on country-level determinants which affect the sustainability assurance are given below:

\subsection{Stakeholder's Orientation and Sustainability Assurance}

Stakeholder's theory suggests, "Business Corporations need to create a valuable relationship with all of their stakeholders, instead of only shareholders, and they endeavory to satisfy their informational needs through sustainability reports". In recent years, the literature has given clear indications regarding the need to increase stakeholder involvement and participation in sustainability reporting processes. It has been considered that the quality of sustainability reporting is closely linked with the stakeholder engagement. Past studies show that stakeholders-oriented countries positively affect the credibility of sustainability reporting assurance (Romero et al. 2014, Wong and Millington 2014, Cheng et al. 2015). Hodge et al. (2009) argue that Australian students find that sustainability assurance statements positively affect the sustainability report credibility. Organizations which are operating in stakeholder-orientated countries where organizations value stakeholder views more than a shareholder views (Simnett et al. 2009) and countries which have not strong regulatory bodies are more likely to adopt sustainability assurance to encourage disclosure credibility (Kolk and Perego 2010, Perego and Kolk 2012).

Different evidences are observed that an insufficient level of stakeholder engagement is found in assurance processes. Initially O'Dwyer and Owen(2005), in their examinations into a different samples of assurance statements, found many uncertainties on intentions of those people who are assurance providers to engage stakeholders in assurance process. Now-a-days results of some studies have linked the firm 
level and country level factors with the companies' decision to adopt assurance or not on their Sustainability Reporting. In addition, different types of two studies recognized the broader stakeholder view and depend on current CSR reputation ratings (Birkey et al. 2016; Sethi et al. 2015). These studies proposed that CSRA decision and CSRA provider would lead to positive stakeholder reaction, such as high CSR reputation and increased market valuation. If a firm is CSR provider, this was result of positive stakeholder reaction (Casey and Grenier, 2015). Corporate social responsibility reports have been a main tool for corporations in developing the linkage with their stakeholders. CSRA decisions and the selection of big audit firms as a CSRA provider also leads to a positive stakeholder reaction (such as increased market valuation and high CSR reputation). According to the Casey and Grenier 2015; if the firm was the CSRA provider, there was possibility of positive stakeholder's reactions, while (Sethi et al. 2015) found that firm size is negatively related to the stakeholder's reaction.

In USA, 351 firm-year observations (2009-2010) found a positive result to conduct a CSRA with a dependent variable of stakeholder's reaction. In Italy, 237 firms' observations (2008-13) while adopting mix (legitimacy and stakeholder theory) found no significant result to conduct the CSRA (Fazzini and Dal Maso: Sustainability Accounting, Management and Policy Journal). Edgley et al.(2010) claim that engagement of stakeholders in assurance is likely to increase in future.

Mixed results from the past studies are found on the issue. This study hypothesizes as under:

H1: The countries which are stakeholder-oriented are more likely to adopt the third-party assurance over their sustainability reports.

\subsection{Investors' Protection and Sustainability Assurance}

The level of Investor's protection in a country also impacts various organisational practices in a country. It exerts extra pressure and incentivises managers to fulfil the demand of investors. Evidence on the impact of investors' protection on sustainability assurance is mixed in existing literature. According to Herda et al. (2014), companies that operate in countries with weaker investors' protection tend to adopt sustainability assurance (klapper and Love, 2004). Those firms which are weaker in investors' protection are more willing to bear the cost to enhance credibility for shareholders (klapper and Love, 2004).

There is substantial variation in sustainability assurance scope and procedure (O'Dwyer and Owen, 2005, 2007). The main reason for this variation in assurance quality is that the reporting corporations have considerable engagement in selection of assurance procedures performed. Most of the studies indicate that those countries which are weaker in investors' protection are more likely to obtain the assurance. We hypothesize that,

H2: The countries which are weaker in investors' protection are more likely to adopt the third party assurance over their sustainability reports.

\subsection{Rule of Law and Sustainability Assurance}

In Business and legal environment, the role of other stakeholder groups is less emphasized. Prior research in accounting indicates that there is an increased demand for information on a firm's financial performance. Tendency of rule of law have positive relationship with CSRA. After studying results, it can be interpreted that impact of rule of law and CSRA both have positive (Sethi et al. 2015; Simnett et al. 2009) and negative relationship (Kolk and Perego 2010; Perego 2009). A probable situation reveals that negative impact of enforcement on CSRA might be due to changing governance instrument in a weaker legal enforcement government.

696 Transnational firms (2007-2014) while adopting stakeholder agent theory with Country characteristics variables found positive result to conduct a CSRA (Martinez-Ferrero and Garcia SanchezInternational Business review). De Beelde and Tuybens-Business strategy and the environment found negative result to conduct a CSRA with sample of transnational (12 countries in Europe) of 227 
companies while using stakeholder agent theory. Kolk and Pergo found negative result of legal enforcement to conduct CSRA in transnational (20 countries, 212 fortune and 250 global companies). Simmett et al(2009) found positive results to conduct CSRA while having legal enforcement in transnational (31 countires-2113 companies)

Different results are drawn from the literature like they conclude positive and negative relationship. Majority of studies shows the negative relationship and this study hypothesize as:

H3: The countries which have weaker tendency of rule of law are more likely to adopt the third-party assurance over their sustainability reports.

\subsection{Voice, Accountability and Sustainability Assurance}

Stakeholders require transparency of CSR reporting (Moneva et al. 2006; Ramus and Montiel 2005). Firms start to provide CSRA which would require third party to improve the accountability and credibility. The content of the assurance statements of CSR reports inspect the mark to which assurance practises cover the different issues of stakeholder's interests and to maintain the corporate image to stakeholders.Accordingly, the main theme of previous studies is:

- The degree to which assurance statements uplift and maintain the corporate image and accountability to stakeholders.

- Others problems are highlighted and conferred to degree they linked with the problems of company accountability to their stakeholders.

Different studies on these problems are linked for various causes. Initially, early literature in the developing times of sustainability reporting and assurance, suggests that involvement of stakeholders and their interest are imaginary in the assurance process, it does not permit a firm view to the degree in which the phenomena is obstinate because, the practises of gaining the third party assurance statements over their sustainability reports was recently developed in which triple-bottom-line reports were emerged in their early stages. Latterly, due to drastic need to increase in demand for gaining the their party assurance of their CSR (KPMG, 2008), the practises of assurance has been comprised on the plan of various standard setting bodies and Not-for-profit companies. E.g., the IAASB have established an assurance standard. The not-for-profit organization accountability also established its own standards: AA1000AS. Additionally, the development of Sustainability Accounting Standards Board in USA in July, 2011, along with the emergence of integrated reporting (IR), it is perceived that problems of corporate Sustainability Assurance and their associates will gain high push. Additionally, the assurance practises in examined the greater development with the adaptability of growing trends in this segment. The SA is on early stages in its evolution (GRI2013) and research in this significant area contribute to the assurance practises and their standard setting process.

This study hypothesizes as:

H4: The countries who have stronger voice and accountability tendencies are morelikely to adopt the third-party assurance over their sustainability reports.

\subsection{Long-Term Orientation and Sustainability Assurance}

No past study is found which assumed that companies situated in those societies which have a strongvalues of feminism, collectivism, tolerance of uncertainty and long-term orientation would be a higher commitment towards CSRA (Garcia-Sanchez et al. 2013). In our study we take a Long-term orientation dimension as our independent variable along others. We hypothesize that:

H5: The countries who have long-term orientation are more likely to adopt the third-party assurance over their sustainability reports. 


\section{Research Methodology}

\subsection{Population and Sample}

All companies that are listed on the Sustainability Disclosure Database (http://database.globalreporting.org) constitute the population for this study. The sample (196 firms from 41 countries) of this study constitutes firms of large size only from 11 different sectors (Agriculture, automobile, aviation, chemical, computers, conglomerates, foods and beverages, forest and paper products, health care services, mining and tobacco). Large size Firms and sectors are taken as literature suggests that sustainability issues are more important for firms of large size and for these sensitive sectors. From the sustainability disclosure database, filtered data for the year 2017 is taken. Non-GRI reports were excluded.

\subsection{Data Collection}

This study identifies all sustainability reports using data base of global reporting published in 2017 of 11 different sectors which are agriculture, automobile, aviation, chemicals, computers, conglomerates, foods and beverages, forests and paper products, health care services, mining and tobacco. The final sample consists of 196 observations of 563 different organizations. 119 reports are assured out of 196 companies. Our study sample is reduced to 196 from 570 observations. This reduction is because sustainability information is either missing or presented in different languages (non-English).

\subsection{Econometric Model}

Econometric model of our study is,

Assuredi $=\beta 0+\beta 1 \mathrm{INVPROi}+\beta 2 \mathrm{ROLi}+\beta 3 \mathrm{STKHLDOi}+\beta 4 \mathrm{VOACCi}+\beta 5 \mathrm{HOFDi}+\varepsilon \mathrm{i}$

Where Assured :Sustainability Assurance (Dependent variable)

INVPRO:Investor Protection; ROL: Rule of Law; STKHLDO : Stakeholder's Orientation

VOACC: Voice and accountability; HOFD:Hofstede's Dimension Long-term orientation

\subsubsection{Variable Description}

\begin{tabular}{|l|l|}
\hline Variable & Description (Source) \\
\hline $\begin{array}{l}\text { Assurance } \\
\text { (Dependent Variable) }\end{array}$ & $\begin{array}{l}\text { Indicator consists of assured (\%) of reports from Data base of global } \\
\text { reporting, }\end{array}$ \\
\hline $\begin{array}{l}\text { Investor Protection } \\
\text { (Independent Variable) }\end{array}$ & $\begin{array}{l}\text { Investor Protection score is obtained from: } \\
\text { https://tcdata360.worldbank.org/indicators/h2e15b0d6?country=BRA } \\
\text { \&indicator=647\&viz=line_chart\&years=2007,2017 }\end{array}$ \\
\hline $\begin{array}{l}\text { Rule of Law } \\
\text { (Independent Variable) }\end{array}$ & $\begin{array}{l}\text { Rule of Law score is obtained from: } \\
\text { https://worldjusticeproject.org/sites/default/files/documents/WJP- } \\
\text { ROLI-2018-June-Online-Edition_0.pdf }\end{array}$ \\
\hline $\begin{array}{l}\text { Stakeholders Orientation } \\
\text { (Independent Variable) }\end{array}$ & $\begin{array}{l}\text { Stakeholder's orientation is binary variable. 1 for Stakeholders } \\
\text { oriented countries and 0 for others. } \\
\text { https://onlinelibrary.wiley.com/doi/abs/10.1111/jifm.12018 }\end{array}$ \\
\hline
\end{tabular}




\begin{tabular}{|l|l|}
\hline $\begin{array}{l}\text { Voice and Accountability } \\
\text { (Independent variable) }\end{array}$ & $\begin{array}{l}\text { Voice and accountability are to be calculated from: } \\
\text { www.govindicators.org }\end{array}$ \\
\hline $\begin{array}{l}\text { Hofstede dimension } \\
\text { (Longterm Orientation } \\
\text { Independent variable) }\end{array}$ & $\begin{array}{l}\text { Hofstede dimension is taken from, } \\
\text { https://www.hofstede-insights.com/product/compare-countries/ }\end{array}$ \\
\hline
\end{tabular}

\section{Results and Analysis}

\subsection{Descriptive Statistics}

\begin{tabular}{|l|l|l|l|l|l|l|l|}
\hline & $\mathrm{N}$ & $\begin{array}{l}\text { Minimu } \\
\mathrm{m}\end{array}$ & $\begin{array}{l}\text { Maximu } \\
\mathrm{m}\end{array}$ & Mean & $\begin{array}{l}\text { Std. } \\
\text { Deviation }\end{array}$ & $\begin{array}{l}\text { Kurtos } \\
\text { is }\end{array}$ & \\
\cline { 2 - 8 } & $\begin{array}{l}\text { Statis } \\
\text { tic }\end{array}$ & $\begin{array}{l}\text { Statisti } \\
\mathrm{c}\end{array}$ & Statistic & Statistic & Statistic & $\begin{array}{l}\text { Statist } \\
\text { ic }\end{array}$ & Std. Error \\
\hline Assured & 41 & 0.00 & 1 & .627 & .310 & -1.009 & .724 \\
\hline HOFD & 41 & 13 & 100 & .520 & .221 & -.723 & .724 \\
\hline INVPRO & 41 & 4.2 & 8.3 & 6.437 & 1.0148 & -.213 & .724 \\
\hline ROL & 41 & .28 & .97 & .6546 & .167 & -1.013 & .724 \\
\hline VOACC & 41 & 6.90 & 100 & .667 & .280 & -.771 & .724 \\
\hline STKHLDO & 41 & 0 & 1 & .71 & .461 & -1.164 & .724 \\
\hline
\end{tabular}

This table explains the descriptive statistics of the sample companies. In this table, we describe mean value, minimum, maximum and standard deviation of each variable and this indicates normality of the data.

Minimum value of Assured (Sustainability Assurance) is 0 while maximum value is 1, and mean statistics is .627. First independent variable is HOFD (Hofstede's dimension-Long Term Orientation). Its minimum value is 13 and maximum value is 100 whereas mean statistics are .52 and standard deviation is .221 . Second independent variable is INVPRO. It ranges from 4.2 to 8.3 with mean of 6.4 and standard deviation of 1.01. ROL (Rule of Law) is the third independent variable. Its minimum value is .28 and maximum value is .97 , mean statistics is 0.655 and standard deviation is .167. Its data shows normality behaviour as its standard deviation<mean statistics. Fourth independent variable is VOACC (Voice and Accountability) which ranges from minimum statistical value of 6.90 to maximum value of 100, with mean statistics of .667 and standard deviation is .28. Our data is normal in behaviour because mean statistics is greater than the standard deviation. The last and fifth independent variable is STKHLDO (Stakeholders orientation). Its minimum statistical value is 0 and maximum 1 while itss mean statistics is .71 and standard deviation is .461 . The results interpret that the data is normal in behaviour because its mean statistics is greater than the standard deviation. 


\begin{tabular}{|l|l|l|l|l|l|l|l|}
\hline \multicolumn{9}{|c|}{ Correlation Matrix } \\
\hline \multicolumn{2}{|l|}{} & Assured & HOFD & $\begin{array}{l}\text { INVPR } \\
\text { O }\end{array}$ & ROL & VOACC & $\begin{array}{l}\text { STKHLD } \\
\text { O }\end{array}$ \\
\hline Assured & $\begin{array}{l}\text { Pearson } \\
\text { Correlation }\end{array}$ & 1 & $.266^{*}$ & $-.311^{*}$ & -.004 & .235 & .088 \\
\hline HOFD & $\begin{array}{l}\text { Pearson } \\
\text { Correlation }\end{array}$ & & 1 & -.225 & .228 & -.029 & .198 \\
\hline INVPRO & $\begin{array}{l}\text { Pearson } \\
\text { Correlation }\end{array}$ & & & 1 & .105 & .086 & -.180 \\
\hline ROL & $\begin{array}{l}\text { Pearson } \\
\text { Correlation }\end{array}$ & & & & 1 & $.753^{* *}$ & .177 \\
\hline VOACC & $\begin{array}{l}\text { Pearson } \\
\text { Correlation }\end{array}$ & & & & & 1 & $.271^{*}$ \\
\hline $\begin{array}{l}\text { STKHLD } \\
\text { O }\end{array}$ & $\begin{array}{l}\text { Pearson } \\
\text { Correlation }\end{array}$ & & & & & & 1 \\
\hline$*$ Correlation is significant at the 0.05 level (2-tailed). & & & \\
\hline$* *$ Correlation is significant at the 0.01 level (2-tailed). \\
\hline
\end{tabular}

This table explains the correlation among all the variables. Our dependent variable is Assurance and remaining five are independent variables. Sustainability Assurance has significant positive relationship with Hofstede's dimension (Long term Orientation) and positive insignificant relation with VOACC as well as with stakeholder-orientation. The assurance is significantly negatively correlated with Investors' protection and has an insignificant positive relation with rule of law.

\subsection{Regression Results}

\begin{tabular}{|l|l|l|l|l}
\hline Model & Coefficient & $\begin{array}{l}\text { Standard } \\
\text { Error }\end{array}$ & t-value & Significance \\
\hline Constant & 107.31 & 33.82 & 3.17 & 0.003 \\
\hline HOFD & 0.57 & 0.22 & 2.62 & 0.013 \\
\hline INVPRO & -7.49 & 4.37 & -1.72 & 0.095 \\
\hline ROL & -118.73 & 42.07 & -2.82 & 0.008 \\
\hline VOACC & 0.87 & 0.25 & 3.49 & 0.001 \\
\hline STKHLDO & -9.22 & 9.90 & -0.93 & 0.358 \\
\hline & R-Square:0.36 & $\begin{array}{l}\text { Adjusted R- } \\
\text { square } \\
0.27\end{array}$ & $\begin{array}{l}\text { Durbin } \\
\text { Watson } \\
2.21\end{array}$ & \\
& & 2.21 & \\
\hline
\end{tabular}

Adjusted R-square is 0.27 which means that overall effect of the opted independent variables is modest on the sustainability assurance and some other variables also affect the assurance level of the companies.

\subsection{Result Analysis}

According to level of significance we conclude that,

- First hypothesis: "The countries which have long-term orientation are more likely to adopt the thirdparty assurance over their sustainability reports" is accepted.

- Second hypothesis: "The countries which have weaker investors' protection are more likely to adopt the third-party assurance over their sustainability reports" is accepted. 
- Third hypothesis: "The countries with weaker tendency of rule of law are more likely to adopt the third-party assurance over their sustainability reports" is accepted.

- Fourth hypothesis: "The countries having stronger voice and accountability tendencies are more likely to adopt the third-party assurance over their sustainability reports" is accepted.

- Fifth hypothesis: "The countries which are stakeholder-oriented are more likely to adopt the thirdparty assurance over their sustainability reports" is rejected.

\section{Conclusion}

The main objective of this research study is to check the relationship of country level determinants with the independent third-party assurance over their sustainability reports. Earlier studies show that some authors find one-to-one relationship with the sustainability assurance and no past studies are found related to the Hofstede's dimension with the sustainability assurance. In our study, we find the relationship of the Hofstede's dimension (Long-term orientation) with the sustainability assurance and conclude that those countries who have long term orientation are more likely to adopt the sustainability assurance over their sustainability assurance.

The findings indicate that companies which are situated in those countries which are long-term oriented are more likely to adopt the CSRA. Secondly, companies which are operating in those countries which have weaker investors' protection adopt more CSRA to increase their credibility by bearing the extra cost. Thirdly, companies which are operating in countries with weaker tendency of rule of law are also more likely to adopt the CSRA. Fourth, those companies which are operating in those countries who have stronger voice and accountability tendencies are more likely to adopt the CSRA. Lastly, the companies which are operating in stakeholder orientated countries are less likely to adopt the CSRA.

Results however signal that companies preparing reports better manage their credibility through the assurance. Conclusively, sustainability assurance is more relevant. This relevancy might play an important role in motivating the companies that do not prepare reports.

\section{References}

AA1000AS (AA1000 Assurance Standard), Available at http://www.accountability.org (2008).

Birkey, R., Michelon, G., Patten, D. M., \& Sankara, J. (2016). Does assurance on CSR reporting enhance environmental reputation? An examination in the US context.

Coram, P. J., Monroe, G. S., \&Woodliff, D. R. (2009). The value of assurance on voluntary nonfinancial disclosure: An experimental evaluation. Auditing: A Journal of Practice \& Theory, 28(1), 137151.

Cormier, D., Magnan, M., \& Van Velthoven, B. (2005). Environmental disclosure quality in large German companies: economic incentives, public pressures or institutional conditions? European accounting review, 14(1), 3-39.

Cohen, J. R., \&Simnett, R. (2014). CSR and assurance services: A research agenda. Auditing: A Journal of Practice \& Theory, 34(1), 59-74.

Cohen, J., L. Holder-Webb, L. Nath and D. Wood, "Retail Investors' Perceptions of the Decision-Usefulness of Economic Performance, Governance, and Corporate Social Responsibility Disclosures," Behavioral Research in Accounting 23 (2011), pp. 109-129.

De Villiers, C. and C. J. Van Staden, "Shareholders' Requirements for Corporate Environmental Disclosures: A Cross Country Comparison," The British AccountingReview 42 (2010), pp. 227240.

De Villiers, C. and C. J. Van Staden, "Shareholders' Requirements for Compulsory Environmental Information in Annual Reports and on Websites," Australian Accounting Review 21 (2011), pp. 317-326 
De Beelde, I., \&Tuybens, S. (2015). Enhancing the credibility of reporting on corporate social responsibility in Europe. Business Strategy and the Environment, 24(3), 190-216.

Fama, E. F., \& Jensen, M. C. (1983). Separation of ownership and control. The journal of law and Economics, 26(2), 301-325.

FAROOQ, M. B., \& DE VILLIERS, C. Assurance of Sustainability and Integrated Reporting.

Fazzini, M., \& Dal Maso, L. (2016). The value relevance of "assured" environmental disclosure: The Italian experience. Sustainability Accounting, Management and Policy Journal, 7(2), 225-245.

GRI (Global Reporting Initiative). Available at http://www.globalreporting.org (2010)

Herda, D. N., Taylor, M. E., \&Winterbotham, G. (2014). The effect of country-level investor protection on the voluntary assurance of sustainability reports. Journal of International Financial Management \& Accounting, 25(2), 209-236.

Junior, R. M., Best, P. J., \& Cotter, J. (2014). Sustainability reporting and assurance: A historical analysis on a world-wide phenomenon. Journal of Business Ethics, 120(1), 1-11.

Kolk, A., \& Perego, P. (2010), Determinants of the adoption of sustainability assurance statements: An international investigation. Business Strategy and the Environment, 19(3), 182-198.

Kend, M. (2015). Governance, firm-level characteristics and their impact on the client's voluntary sustainability disclosures and assurance decisions. Sustainability Accounting, Management and Policy Journal, 6(1), 54-78.

KPMG, "KPMG International Survey of Corporate Responsibility Reporting 2008," Available at http://www.kpmg.com (2008).

KPMG, "KPMG International Survey of Corporate Responsibility Reporting 2011," Available at http://www.kpmg.com (2011). La Porta, R., F. Lopez-de-Silanes, A. Shleifer and R. Vishny, "Law and Finance," Journal of Political Economy $106 \quad$ (1998), pp. 1113-1155. La Porta, R., F. Lopez-de-Silanes, A. Shleifer and R. Vishny, "Investor Protection and Corporate Governance," Journal of Financial Economics 58 (2000), pp. 3-27

Lamberton, G. (2005, March). Sustainability accounting-a brief history and conceptual framework. In Accounting Forum(Vol. 29, No. 1, pp. 7-26). Elsevier.

Meek, G. K., Roberts, C. B., \&Gray, S. J. (1995). Factors influencing voluntary annual report disclosures by US, UK and continental European multinational corporations. Journal of international business studies, 26(3), 555-572.

Manetti, G. (2011). The quality of stakeholder engagement in sustainability reporting: empirical evidence and critical points. Corporate Social Responsibility and Environmental Management, 18(2), 110122.

Mitchell, R. K., Agle, B. R., \& Wood, D. J. (1997). Toward a theory of stakeholder identification and salience: Defining the principle of who and what really counts. Academy of management review, 22(4), 853-886.

Moneva, J. M., Archel, P., \& Correa, C. (2006, June). GRI and the camouflaging of corporate unsustainability. In Accounting forum (Vol. 30, No. 2, pp. 121-137). Elsevier.

O'Dwyer, B., \& Owen, D. L. (2005). Assurance statement practice in environmental, social and sustainability reporting: a critical evaluation. The British Accounting Review, 37(2), 205-229.

O'Dwyer, B. and D. Owen, "Assurance Statement Practice in Environmental, Social and Sustainability Reporting: A Critical Evaluation," The British Accounting Review 37 (2005), pp. 205-229.

O’Dwyer, B. and D. Owen, "Seeking Stakeholder-Centric Sustainability Assurance: An Examination of Recent Sustainability Assurance Practice," The Journal of Corporate Citizenship $25 \quad$ (2007), $\quad$ pp. 77-94. O’Dwyer, B., D. Owen and J. Unerman, "Seeking Legitimacy for New Assurance Forms: The Case of Assurance on Sustainability Reporting," Accounting, Organizations and Society 36 (2011), pp. 31-52.

Perego, P., \& Kolk, A. (2012). Multinationals' accountability on sustainability: The evolution of thirdparty assurance of sustainability reports. Journal of Business Ethics, 110(2), 173-190. 
Ramus, C. A., \& Montiel, I. (2005). When are corporate environmental policies a form of greenwashing?. Business \& Society, 44(4), 377-414.

Simnett, R., Vanstraelen, A., \& Chua, W. F. (2009). Assurance on sustainability reports: An international comparison. The accounting review, 84(3), 937-967.

Sandler, R. S., Everhart, J. E., Donowitz, M., Adams, E., Cronin, K., Goodman, C., ... \& Rubin, R. (2002). The burden of selected digestive diseases in the United States. Gastroenterology, 122(5), 1500-1511.

Velte, P., \&Stawinoga, M. (2017). Empirical research on corporate social responsibility assurance (CSRA): A literature review. Journal of Business Economics, 87(8), 1017-1066.

Wong, R., \& Millington, A. (2014). Corporate social disclosures: a user perspective on assurance. Accounting, Auditing \& Accountability Journal, 27(5), 863-887. 
